\title{
David Oliver: Is NHS "candour" on a break for winter?
}

\author{
David Oliver consultant in geriatrics and acute general medicine
}

Berkshire

Winter seems more difficult each year in NHS acute care, and 2016-17 is no exception. Vocal public support from national leadership bodies would be a welcome New Year gift. It would certainly beat attempts at news management to limit reputational damage and appease politicians' reported wishes to keep hospital crises out of the headlines. ${ }^{1}$

Looking at NHS performance statistics, ${ }^{2}$ media reports of clinicians' tales from around the country, ${ }^{3}$ or statements from their medical colleges and societies, ${ }^{45}$ it's been more like the Apocalypse than the Christmas story. Demand for urgent care is high, and hospitals are crammed, under extreme pressure to clear beds. An exit block continues, ${ }^{6}$ whereby stranded patients await overwhelmed community services that can't match demand.

Trapped in the middle are frontline staff under almost unbearable pressure- the King's Fund's Chris Ham refers to them as "shock absorbers." ${ }^{7}$ We're forced to pick one uncomfortably risky option over another, as we juggle the system's needs with those of individual patients.

When things go wrong it will be jobbing clinicians who face patient complaints and attend inquests, not Whitehall officials

Even more trapped are the patients themselves: on trolleys in corridors, stuck in ambulances outside emergency departments, diverted to other hospitals, or discharged earlier than they or staff would like, without enough chance for planning. When things go wrong it will be jobbing clinicians who face the complaints of patients and their families and attend inquests, not Whitehall officials.

The British Red Cross, one of several charities that do great work to support people leaving hospital or trying to remain at home, said last week that the situation in English hospitals in recent weeks had become a "humanitarian crisis." It illustrated its claim with stories of patients discharged in haste without the right support at home.

On the same day, the Telegraph reported leaked memos from NHS England essentially instructing acute service managers to play down the extent of problems. ${ }^{9}$ The article reported a script containing lines for standard use to minimise public concern,
"The most important thing" being to avoid negative language. NHS England then said that, as its winter planning was the best it had ever been, the Red Cross's statement had no justification.

Another recent "leaked memo" story found NHS England telling supposedly locally owned sustainability and transformation plans how positive to make their public communications. ${ }^{10}$

The government's response to the Francis report made the duties of candour and transparency statutory. ${ }^{11}$ This applies from frontline clinicians to board level NHS managers. In turn, this means a duty of transparency to the local patients, population, and press: transparency about unavailable beds, staffing gaps, funding crises, risks to safe care, and unavailable step-down care. It does not mean a "Crisis? What crisis?" denial of serious issues.

Competing interests: See www.bmj.com/about-bmj/freelancecontributors/david-oliver.

Provenance and peer review: Commissioned; not externally peer reviewed.

Follow David on Twitter, @mancunianmedic

Campbell D. No extra money for NHS, Theresa May tells health chief. Guardian 2016 Oct 14. https://www.theguardian.com/politics/2016/oct/14/no-extra-money-for-nhs-theresamay-tells-health-chief.

2 Murray R, Jabbal J, Thompson J, Baird B, Maguire D, Northern E. How is the NHS performing? Quarterly monitoring report November 2016. 16 Nov 2016. https://www. kingsfund.org.uk/publications/articles/how-nhs-performing-november-2016.

3 Campbell D. "The worst conditions in memory": NHS doctors describe a week in A\&E. Guardian 2017 Jan 8. https://www.theguardian.com/society/2017/jan/08/an-absolutewarzone-nhs-doctors-describe-their-week-in-ae.

4 Winter from hell" has arrived-doctor's NHS crisis warning. BBC News 2017 Jan 7. www. bbc.co.uk/news/health-38541462.

5 Weaver M, Siddique $\mathrm{H}$. Press Association. NHS on brink of winter crisis after increase in patient numbers. Guardian 2017 Jan 6. https://www.theguardian.com/society/2017/jan/ 06/nhs-winter-crisis-increase-patient-numbers-hospital-trusts.

6 National Audit Office. Discharging older patients from hospital. 26 May 2016. https://www. nao.org.uk/wp-content/uploads/2015/12/Discharging-older-patients-from-hospital.pdf.

7 Ham C. UK government's autumn statement: no relief for NHS and social care in England. BMJ 2016;356:6382. doi:10.1136/bmj.i6382 pmid:27895072.

8 Campbell D, Morris S, Marsh S. NHS faces "humanitarian crisis" as demand rises, British Red Cross warns. Guardian 2017 Jan 6. https://www.theguardian.com/society/2017/jan/ 06/nhs-faces-humanitarian-crisis-rising-demand-british-red-cross.

9 Donnelly L. "Humanitarian crisis" in NHS warns British Red Cross as A\&Es are overwhelmed by demand. Telegraph 2017 Jan 6. www.telegraph.co.uk/news/2017/01 06/crisis-crisis-nhs-accused-trying-spin-way-trouble/.

10 Dunhill L. Revealed: NHS England checklist for making STP details public. Health Serv $J 2016$. 
11 Department of Health. Hard truths: the journey to putting patients first. Jan 2014. https:// www.gov.uk/government/uploads/system/uploads/attachment_data/file/270368/34658_ Cm_8777_Vol_1_accessible.pdf.
Published by the BMJ Publishing Group Limited. For permission to use (where not already granted under a licence) please go to http://group.bmj.com/group/rights-licensing/ permissions 